\title{
Towards a better understanding of microbial carbon flux in the sea*
}

\author{
Josep M. Gasol ${ }^{1, * *}$, Jarone Pinhassi ${ }^{2, * *}$, Laura Alonso-Sáez ${ }^{3}$, Hugh Ducklow ${ }^{4}$, \\ Gerhard J. Herndl ${ }^{5}$, Michal Koblížek ${ }^{6}$, Matthias Labrenz ${ }^{7}$, Yawei Luo ${ }^{4}$, \\ Xosé Anxelu G. Morán ${ }^{4,8}$, Thomas Reinthaler ${ }^{5}$, Meinhard Simon ${ }^{9}$ \\ ${ }^{1}$ Institut de Ciències del Mar-CSIC, Pg. Marítim de la Barceloneta 37-49, 08003 Barcelona, Catalunya, Spain \\ ${ }^{2}$ School of Pure \& Applied Natural Sciences, University of Kalmar, 39182 Kalmar, Sweden \\ ${ }^{3}$ Department of Ecology \& Evolution, Limnology group, Uppsala University, PO Box 573, 75123 Uppsala, Sweden \\ ${ }^{4}$ The Ecosystems Center, Marine Biological Laboratory, Woods Hole, Massachusetts 02543, USA \\ ${ }^{5}$ Dept. Biological Oceanography, Royal Netherlands Institute for Sea Research (Royal NIOZ), PO Box 59, 1790 AB Den Burg, \\ The Netherlands \\ ${ }^{6}$ Institute of Microbiology CAS, Opatovický mlýn, 37981 Trebon and Institute of Physical Biology JU, Zámek 136, \\ 37333 Nové Hrady, Czech Republic \\ ${ }^{7}$ IOW-Leibniz Institute for Baltic Sea Research, Seestrasse 15, 18119 Rostock-Warnemünde, Germany \\ ${ }^{8}$ Centro Oceanográfico de Xixón, Instituto Español de Oceanografía, Camín de L'Arbeyal, s/n, 33212 Xixón, Spain \\ ${ }^{9}$ Institute for Chemistry and Biology of the Marine Environment, University of Oldenburg, 26111 Oldenburg, Germany
}

\begin{abstract}
We now have a relatively good idea of how bulk microbial processes shape the cycling of organic matter and nutrients in the sea. The advent of the molecular biology era in microbial ecology has resulted in advanced knowledge about the diversity of marine microorganisms, suggesting that we might have reached a high level of understanding of carbon fluxes in the oceans. However, it is becoming increasingly clear that there are large gaps in the understanding of the role of bacteria in regulating carbon fluxes. These gaps may result from methodological as well as conceptual limitations. For example, should bacterial production be measured in the light? Can bacterial production conversion factors be predicted, and how are they affected by loss of tracers through respiration? Is it true that respiration is relatively constant compared to production? How can accurate measures of bacterial growth efficiency be obtained? In this paper, we discuss whether such questions could (or should) be addressed. Ongoing genome analyses are rapidly widening our understanding of possible metabolic pathways and cellular adaptations used by marine bacteria in their quest for resources and struggle for survival (e.g. utilization of light, acquisition of nutrients, predator avoidance, etc.). Further, analyses of the identity of bacteria using molecular markers (e.g. subgroups of Bacteria and Archaea) combined with activity tracers might bring knowledge to a higher level. Since bacterial growth (and thereby consumption of DOC and inorganic nutrients) is likely regulated differently in different bacteria, it will be critical to learn about the life strategies of the key bacterial species to achieve a comprehensive understanding of bacterial regulation of $\mathrm{C}$ fluxes. Finally, some processes known to occur in the microbial food web are hardly ever characterized and are not represented in current food web models. We discuss these issues and offer specific comments and advice for future research agendas.
\end{abstract}

KEY WORDS: Carbon flux · Microbial ecology · Ocean · Bacteria $\cdot$ Protists $\cdot$ Light $\cdot$ Genomics Chemoautotrophy $\cdot$ Models

Resale or republication not permitted without written consent of the publisher

\section{INTRODUCTION}

Most manuscripts, particularly in journals not exclusively devoted to microbial ecology, start with a sentence of the type 'bacteria (or prokaryotes) are very relevant in carbon flux in the ocean (or in lakes)' . A few general references are used to back up the sentence. The conceptual role of prokaryotes is commonly depicted with reference to early schemes of the 'microbial loop' concept (Pomeroy 1974, Williams 1981,

**Emails: pepgasol@icm.csic.es, jarone.pinhassi@hik.se 
Azam et al. 1983), or to revised versions of the microbial food network (Sherr \& Sherr 1988, 2000). This reflects what most oceanographers, limnologists and ecologists consider to be the primary role of prokaryotes in the food web processes involving carbon and energy fluxes.

In recent years, however, aquatic microbial ecology has generated evidence indicating that things are not as simple as these schemes suggest. Our research area has shifted from the measurement of processes at the bulk level to the determination of single cell activity, to increased isolations of bacteria which are thought to be relevant in the environment, and to the generation of data from environmental genomics techniques (DeLong \& Karl 2005). We now know that non-photosynthetic prokaryotes use light energy (e.g. Fenchel 2001, Karl 2002) and dissolved and particulate organic matter (DOM and POM) is used by prokaryotes that were previously considered to be strictly phototrophic (e.g. Zubkov et al. 2003, 2004, Zubkov \& Tarran 2005, VilaCosta et al. 2006, Unrein et al. 2007), that chemoautotrophic metabolisms seem to dominate even in well-oxygenated areas of the deep ocean (Herndl et al. 2005), and that coastal ocean carbon metabolism mediated by bacteria might include lithoheterotrophic metabolisms (Moran \& Miller 2007), etc. Considering this, how should we depict the microbial food web? And, if we are set to study the functioning of the microbial food web, are we accurately quantifying the role of prokaryotes when we use, e.g., leucine or thymidine to determine biomass or cell production?

When interacting with ecosystem or biogeochemical modelers, a further relevant issue is to determine the level of resolution required for the 'bacterioplankton (sensu prokaryotic) black box'. We know that diversity at a given site is large or even very large according to some estimates based on new techniques (e.g. Sogin et al. 2006), but we also know that bacterial groups or clusters dominating in different marine environments differ (e.g. Pommier et al. 2007), with biogeographical trends clearly following oceanography (Selje et al. 2004). It is true that we do not fully understand the ecological consequences of the described bacterial (micro) diversity (Acinas et al. 2004, Thompson et al. 2005), but we have been able to show clear trends in the use of selected molecular weight size fractions and molecular types by large phylogenetic groups (e.g. Cottrell \& Kirchman 2000, Alonso-Sáez \& Gasol 2007), indicating that most bacteria within a specific cluster seem to behave similarly, at least on a general functional level. However, as revealed in a study testing the effect of photosynthetically active radiation (PAR) and ultraviolet (UV) radiation on different groups of marine bacteria, the phylogenetic level targeted by the oligonucleotide probe was decisive for the outcome of the experiment (see sections 'A specific example: bacteria on the dark side' and 'Role of aerobic anoxygenic phototrophs in the marine carbon cycle' below). What level is 'the right one' for biogeochemical modelers? All prokaryotes? Broad phylogenetic groups such as Alphaproteobacteria/Gammaproteobacteria? More specific groups, such as SAR11/Roseobacter? An additional issue concerns the characterization of the environment. SAR11 is known to be the most common prokaryotic group in the surface ocean (Morris et al. 2002, Rappé et al. 2002), dominating clone libraries (Giovannoni \& Rappé 2000) and also as detected by fluorescence in situ hybridization (FISH). However, SAR11 is neither dominant in the Baltic Sea (Riemann et al. 2008) nor at some Atlantic coastal sites (e.g. Henriques et al. 2004) and, in fact, is a whole clade comprised of many ecotypes (Field et al. 1997), probably with different functioning and habitat selectivity. Mediterranean SAR11 bacteria seem to participate much less in the ocean carbon cycle than central Atlantic SAR11 (Malmstrom et al. 2005, Alonso-Sáez \& Gasol 2007). Overall, SAR11 might not necessarily be the most biogeochemically important marine bacteria with respect to carbon cycling.

Our conceptual representation of the planktonic ecosystem often assumes a large degree of spatial homogeneity. Certainly, bacterial communities seem to be rather similar at relatively large spatial scales (Acinas et al. 1997, Baldwin et al. 2005) on the horizontal axis, except where different water masses meet (Suzuki et al. 2001, Pinhassi et al. 2003). At the same time, they are quite diverse at different depths, with bacterial groups occurring in defined layers (e.g. SAR202, Morris et al. 2004, Varela et al. 2008). Different metabolisms seem to be dominant in different layers, particularly at sites with anoxic interfaces and redoxclines (e.g. Taylor et al. 2001), but not only there (DeLong 2005). The metabolic changes with depth are just an extreme example of the fact that the oceanic upper layers may be biogeochemically variable in different parts of the world's oceans (see section 'Refined functional and regional resolution').

A workshop at the 10th Symposium on Aquatic Microbial Ecology (SAME) held in Faro in 2007 provided a valuable opportunity to discuss some of these issues. This paper explains some of the main concepts underlined by the workshop speakers and presents some open questions and conclusions that should be taken into account in future research. The different sections will hopefully provide a diverse but coherent view of gaps in our current knowledge on the ecology of aquatic microbes.

Throughout this paper, we will use 'bacteria' or 'prokaryotes' synonymously, referring to Bacteria and Archaea that have metabolisms considered to be 
mainly chemoorganoheterotrophic. The term 'microbes' will be used to refer to the above 2 groups of organisms as well as to autotrophs, viruses, and protists. While we are aware of the artificiality of the term 'prokaryote' (Pace 2006), we will use it to make the text less cumbersome.

\section{HOW ACCURATELY ARE WE MEASURING BACTERIAL ACTIVITIES?}

Chemoorganoheterotrophic bacteria are probably the most abundant metabolic type in the upper layers of the ocean (but see sections below). They incorporate low molecular weight (LMW) organic molecules which can be catabolized to $\mathrm{CO}_{2}$ (to obtain energy, ATP, and reducing power for anabolism), or used for biosynthesis. If the available organic carbon is in the form of high molecular weight (HMW) molecules, which cannot pass the cell's membranes, bacteria produce extracellular enzymes that cleave the molecule to generate LMW molecules (<600 Da), which can subsequently be taken up. The term bacterial growth efficiency (BGE) is used to describe the partitioning of the total organic carbon taken up by bacteria (i.e. bacterial carbon demand) into either respiration or production of biomass. By far the most popular methods to determine bacterial production are the measurement of the incorporation of radiolabeled thymidine or leucine into bacterial DNA (Fuhrman \& Azam 1980) or protein (Kirchman et al. 1985, Simon \& Azam 1989). Recently, and driven by the increasing regulations limiting the use of radioactive tracers on ships and in laboratories, bromodioxyuridine (BrDU) incorporation into DNA has been introduced (e.g. Nelson \& Carlson 2005). All these methods require conversion factors to calculate cell or biomass production rates which, if not constant, may severely influence the final bacterial production estimate. Most notably, conversion factors for leucineto-carbon and thymidine-to-cells production measurements may vary by a factor of 10 , even within the same study (e.g. Sherry et al. 2002, Alonso-Sáez et al. 2007), although they generally range within a factor of 2 to 4 .

Measurement of bacterial respiration is not straightforward either. Not only are the rates in oligotrophic environments low, but the target value is the respiration of the heterotrophic prokaryotes alone, and separating bacteria from protists is not simple due to overlaps in the size of target organisms. Particularly in the most oligotrophic environments, non-photosynthetic Bacteria and Archaea have sizes of ca. $0.6 \mu \mathrm{m}$ in diameter, while Prochlorococcus cells are ca. $0.8 \mu \mathrm{m}$ and Synechococcus has a size of about $1 \mu \mathrm{m}$ (cf. Sieracki et al. 1995). The smallest photosynthetic protists are about $1.5 \mu \mathrm{m}$ in diameter (Worden et al. 2004), and most heterotrophic nanoflagellates are in the 2 to $3 \mu \mathrm{m}$ range (Jürgens \& Massana 2008), but can squeeze through a pore-size much smaller than their actual size. Furthermore, different filter types allow the passage of different amounts of bacteria and influence the nutrient characteristics of the filtrate to a variable extent (e.g. Gasol \& Morán 1999, Kiene \& Linn 1999), thus potentially affecting the measurement of bacterial processes. In any case, filtration procedures intended to separate protists from the prokaryotic community commonly result in either a variable loss of the original prokaryotic abundance and/or the passage of protists through the filters. Hence, the prokaryotic community might be different from the original community after filtration, with potential consequences for phylogenetic composition and activity. Alternatives to filtration exist (e.g. sonication, antibiotics), but they are not free of problems either.

Unless bacterial respiration (BR) is measured, authors often use an assumed value of BGE to estimate $\mathrm{BR}$ and bacterial carbon demand $(\mathrm{BP}+\mathrm{BR})$ from bacterial production (BP), thus introducing even more variability in the estimates of carbon metabolism, since $\mathrm{BGE}$ is defined as $\mathrm{BP} /(\mathrm{BP}+\mathrm{BR})$. Two empirical equations have largely been used, one estimating BGE from bacterial production (del Giorgio \& Cole 1998) and the other from temperature (Rivkin \& Legendre 2001). However, they all have high data scatter and low predictive capabilities since BGE seems to depend on all these parameters simultaneously (López-Urrutia \& Morán 2007). The review of del Giorgio \& Cole (1998), however, made clear that the previously often used BGEs of $>30 \%$ are too high for the oligotrophic surface ocean.

Incubations for the empirical determination of BGE have another problem: BP can be measured almost instantaneously, but determination of $\mathrm{BR}$ requires long-term incubations ( $24 \mathrm{~h}$ or even more, at least for oligotrophic sites and measured in conjunction with changes in oxygen concentration). The assumption the estimates are based on is that both parameters (BP and $\mathrm{BR}$ ) are constant throughout the incubation, but this is not always the case in surface waters. Briand et al. (2004) tested the stability of BR rates during incubations by carrying out frequent oxygen measurements and found that the respiration rate was only constant in 9 out of 27 cases during the incubation. Often, the changes in BR are relatively unimportant; however, the changes in BP are more important: at times, the initial BP value is lower than the unfiltered BP estimate, perhaps because the most active cells were the largest (i.e. Gasol et al. 1995), or because more active particleattached bacteria had been retained by the filter. Frequently, however, the value after filtration is higher than in the unfiltered sample, and it remains high 
throughout the incubation. Practitioners of BR measurements to estimate BGE are faced with the question of whether they should use the initial BP (with an unfiltered bacterial assemblage), the BP value after filtration, the average throughout the incubation, or some integrated value: BP estimates can vary by more than one order of magnitude depending on that choice (e.g. Alonso-Sáez et al. 2007). It is often advised to measure $\mathrm{BP}$ as the change in bacterial biomass during the incubation, but this simply switches the issue of poorly constrained leucine or thymidine BP measurements to poorly constrained size and biomass bacterial determinations. It would be desirable to have BR methods available that allow for almost instantaneous rate measurements. Measurement of electron transport system (ETS) activity is one such assay, but it requires a conversion factor as well, which may vary depending on the growth status of the bacterial assemblage (see Arístegui et al. 2005). Using the fluorogenic tetrazolium dye 5-cyano-2,3-ditolyl tetrazolium chloride (CTC) is another option, and hopes were high when CTC values were found to correlate with BR (Smith 1998), but the method has several problems that have hampered its widespread use (Sherr et al. 1999). Clearly, more research is needed in that direction.

BGE can also be measured in so-called DOC-degradation experiments (del Giorgio \& Davis 2003), where the decrease in DOC is compared to the increase in POC (or bacterial biomass). These are often called 'long-term' BGE determination experiments, compared to the 'short-term' (i.e. days) BP and BR determinations. The literature, however, has very few examples of direct comparison between the 2 types of estimates, and while Alonso-Sáez et al. (2008) found a good correlation between the two at a coastal Mediterranean site throughout the year, the values from the short- and long-term assays were not exactly the same (the slope was significantly different from 1).

Of course, all long incubations designed to obtain estimates of biogeochemical flux driven by bacteria might be subject to biases due to changes in the structure of the microbial community throughout the incubation. Changes in community structure in dilution cultures or $24 \mathrm{~h}$ incubations have been documented (Fuchs et al. 2000, Massana et al. 2001, Gattuso et al. 2002). As an example, in several incubations with different Southern Ocean waters, the final bacterial assemblage was consistently less diverse than the initial assemblage and was dominated by a small number of similar species (Massana et al. 2001). It appears that the populations selected for in these incubations are those that, in situ, are actively growing but low in abundance due to grazing pressure (Suzuki 1999). However, the parameters estimated by these approaches (BR, BGE, conversion factors, etc.) might have a large 'ecological' component (i.e. several phylotypes respond equally to the same environmental situation) and a small 'phylogenetic' component (different phylotypes respond differently to similar ecological situations). If that were the case, the obtained value would still be meaningful even if the community changes. While these community structure changes cannot be circumvented at present, research geared at testing the role of 'phylogenetic' vs. 'ecological' components of the estimated parameters would be desirable.

In conclusion, estimates of carbon flow through bacteria are very often still too unconstrained. In an interesting exercise, Ducklow et al. (2000) constrained the flow of carbon through bacteria for a Southern Ocean area and calculated the required conversion factors needed to close the budgets. A similar exercise was done for freshwater by Cole et al. (1989). Both papers have received ca. 30 citations to date, meaning they are not among the most cited ones by these authors.

While these exercises may not be popular, constraining and devising the best estimates for conversion factors is extremely valuable, especially for modelers. A modeling paper a few years ago said: 'it seems then that the ratio of leucine incorporation to bacterial production is usually between 2 and $20 \mathrm{~kg} \mathrm{C} \mathrm{mol}^{-1}$ leucine, and that bacterial growth efficiency is between 20 and $70 \%$... so we used a ratio of respiration to leucine incorporation of $4.5 \mathrm{~kg} \mathrm{C} \mathrm{mol}^{-1}$ ' (Harris et al. 2001). One can wonder whether a model that uses a leucineto-carbon conversion factor of $20 \mathrm{~kg} \mathrm{C} \mathrm{mol}^{-1}$ and a BGE of $70 \%$ (altogether $>40$ times our current estimates for the open ocean) can be good at predicting or explaining anything at all.

We discussed above the possibilities of finding surrogates and empirical models to predict BGE. There are some indications that variables such as the leucine-to-carbon factor are also driven by ecology, and that they vary in response to DOC quantity, quality and availability (Pulido-Villena \& Reche 2003), as well as by season (Alonso-Sáez et al. 2008). A sustained effort to describe the ecological processes behind the variability in the factors is needed, and well-constrained empirical relationships would certainly help to reduce errors in determining the role of heterotrophic prokaryotes in the flow of carbon in microbial food webs. On an optimistic note, it should also be stressed that, in spite of all the problems and uncertainties mentioned, we have been able to identify patterns for some of the ecological key variables. As an example, pronounced seasonal dynamics in BP and BGE have been reported (Lemée et al. 2002, Reinthaler \& Herndl 2005). If the current methods were not methodologically robust, we would not find such consistent patterns. 
Finally, studies in the deep ocean have found a linear decrease of oxygen concentration in incubation vessels over up to $100 \mathrm{~h}$, and no stimulation of BP after enclosure (Reinthaler et al. 2006). This might indicate that some of the problems cited above do not apply to deep ocean communities where predation pressure is less strong, and certainly requires further research.

\section{A SPECIFIC EXAMPLE: THE QUESTION OF LIGHT VS. DARK INCUBATIONS FOR ESTIMATING BACTERIAL PRODUCTION}

The existence of diel cycles of heterotrophic bacterial activity, especially at oligotrophic sites, has been long documented (Fuhrman et al. 1985, Gasol et al. 1998). Daily maxima around midday (Gasol et al. 1998) were attributed to a tight coupling between the release of DOM by phytoplankton and its rapid uptake by bacteria, implying a major role of sunlight. However, and despite claims concerning the necessity of evaluating the effects of light conditions on bacterial metabolism (Herndl et al. 1993, Sommaruga et al. 1997, Gasol et al. 1998), most researchers still perform BP incubations in the dark. A survey of all papers reporting results from BP determinations (Leu and/or TdR incorporation) published recently over the course of $1 \mathrm{yr}$ in Aquatic Microbial Ecology [Vol 43(3), July 2006 to Vol 48(2), July 2007] showed that only 3 out of 20 studies included measurements in the light, and 2 of those 3 were specifically aimed at comparing light and dark conditions.

Most studies dealing with the effects of solar radiation on bacterial growth have focused on UV radiation, but we will restrict this analysis of light vs. dark $\mathrm{BP}$ estimates to the PAR region of the irradiance spectrum (400 to $700 \mathrm{~nm}$ ), the wavelength that passes through vials and flasks and is commonly used for determining microbial metabolic rates. There is now compelling evidence that light in the PAR region stimulates Leu incorporation rates relative to dark incubations, ranging from a $10 \%$ increase in the Gulf of Mexico (Aas et al. 1996) and a mean 30\% in a transect across the North Atlantic (Michelou et al. 2007) to dramatic increases of $>100 \%$ in the oligotrophic North Pacific (Church et al. 2004). However, strong light inhibition was also consistently found in the Adriatic (Sommaruga et al. 1997) and the areas of upwelling off the Chilean coast (Hernández et al. 2006). Both inhibitory and stimulatory effects were reported by Morán et al. (2001) and Pakulski et al. (2007), who observed interesting differences between substrates, with overall light Leu stimulation but both stimulation and inhibition of TdR incorporation. Aas et al. (1996) also noted light TdR inhibition parallel to Leu stimulation in their samples. These results are obviously contradictory, but the only 2 studies performing systematic assessments of BP response to light, a sort of BP- irradiance experiment analogous to phytoplankton $\mathrm{P}-\mathrm{E}$ curves, consistently showed positive responses of BP to PAR (Morán et al. 2001, Church et al. 2004). Therefore, maybe we should consider 'light inhibition' as 'dark stimulation' and look for the specific processes responsible for the increase in BP sometimes observed in dark samples.

The mechanisms causing the variable responses of $\mathrm{BP}$ to PAR remain unclear. Several processes have been put forward, including the presence of significant photoheterotrophy in light-enhanced BP samples, either aerobic anoxygenic phototrophy (Kolber et al. 2001, see also section 'Role of aerobic anoxygenic phototrophs in the marine carbon cycle'), or mediated by bacteria containing proteorhodopsin (PR: a retinal-based, light-harvesting protein) (Béjà et al. 2000). Indirect effects through enhanced phytoplanktonic release of DOM due to light stress (Zlotnik \& Dubinsky 1989) have been suggested by Sommaruga et al. (1997) and Morán et al. (2001), and light has been shown to have both a stimulatory and an inhibitory effect on the lability of the DOM itself (Moran \& Zepp 2000). A totally different type of explanation considers cyanobacteria (mostly Prochlorococcus) as the organisms responsible for the uptake of labelled substrates in the light (Zubkov et al. 2003, Church et al. 2004, 2006, Michelou et al. 2007). Finally, a relatively stronger negative impact of light on viruses and protistan grazers compared to bacteria (Sommaruga et al. 1997, Pakulski et al. 2007) and photochemical transformations of extant DOM (Lindell et al. 1995, Benner \& Biddanda 1998, Obernosterer et al. 1999) have also been suggested. Based on the possible mechanisms governing bacterial responses to irradiance listed above, and the likely possibility that 2 or more of these mechanisms can be simultaneously operative, it becomes clear that we are still far from knowing what the relevant controls are. However, incident light, ecosystem trophic status and the composition of bacterial assemblages may help illuminate the elusive question of light vs. dark BP incubations. Thus, higher values of light uptake relative to dark conditions have been found in communities naturally exposed to higher PAR levels along latitudinal (Pakulski et al. 2007) or vertical gradients (A. Calvo-Díaz and X.A.G. Morán unpubl.). Relationships with the trophic state of the ecosystem are suggested by significant correlations between the ratio of dark:light BP and inorganic nutrient concentrations (Morán et al. 2001) although, again, 2 processes might get mixed up: low nutrient supply 
affecting bacteria by influencing the release of DOC by phytoplankton, or directly affecting bacteria (Pausz \& Herndl 1999). Community composition also appears to play an important role. Thus, although alphaproteobacterial activity was similar in light and dark treatments, opposite sensitivities were found for 2 more specific groups: in a study by Alonso-Sáez et al. (2006), PAR was detrimental for SAR11 but enhanced amino acid uptake in Roseobacter, which was likely related to the presence of bacteriochlorophyll-a (BChl a)-containing members within the latter group.

Spatial differences over large geographical scales have been recently assessed in the works of Pakulski et al. (2007) and Michelou et al. (2007), but we are not aware of any published seasonal cycle comparing dark and light BP incubations. Preliminary data obtained during 2006 from the southern Bay of Biscay continental shelf (A. Calvo-Díaz and X.A.G. Morán unpubl.) showed that $67 \%$ of Leu incorporation rates $(\mathrm{n}=80)$ were higher in the light than in the dark, with an annual difference in BP of $25 \%$, illustrating the need to incorporate the light component into our objective of getting more accurate BP measurements.

At present, it seems difficult to come to a consensus concerning the relationship between BP and irradiance, but we can conclude that BP measurements are not equal in the light and dark. To further complicate the question, current determinations of BR are only feasible in the dark. Even if BR was not affected by light, something that seems unlikely if light-enhanced respiration proves to be widespread (Pringault et al. 2007), important consequences for bacterial carbon demand and BGE estimates, and their impact on biogeochemical cycling of carbon, are anticipated. In view of the frequently contradictory results found on the few occasions when BP measurements in the light and dark were compared, our major recommendation for future research is to run parallel dark and light incubations to specifically elucidate the mechanisms responsible for such discrepancies. If short in situ incubations are not feasible, running bacterial incubations in the same containers used for primary production measurements could give us a reasonably good indication or first hint of the effects of natural light conditions on bacterial metabolism. A final major goal, however, should be to understand the effects of all natural radiation (including UV) that either directly affects BP and BR or indirectly affects bacteria through organic matter reactivity and phytoplankton physiology and production. This would allow us to recommend the most adequate conditions in which to run standard determinations of bacterial activity.

\section{ROLE OF AEROBIC ANOXYGENIC PHOTOTROPHS IN THE MARINE CARBON CYCLE}

Current models of marine food webs rely on the classical concept of light-driven primary production conducted by autotrophic phytoplankton supporting all other forms of life represented by strictly heterotrophic consumers fully dependent on fixed organic carbon. This simplistic view has recently been challenged by many studies documenting various mixed metabolic strategies among marine microorganisms such as mixotrophy (consumption of organic matter by eukaryotic phytoplankton) or photoheterotrophy (utilization of light energy by primarily heterotrophic bacteria). Mixotrophy is known to be common among eukaryotic phytoplankton (i.e. dinoflagellates and ciliates), but significant amino acid uptake was recently also documented in Prochlorococcus, the main prokaryotic primary producers of tropical and subtropical oceans (Zubkov \& Tarran 2005). In the year 2000, 2 independent studies documented a widespread ability to utilize light energy among marine bacteria (Béjà et al. 2000, Kolber et al. 2000). The first group of these organisms contains PRs. Organisms containing PR genes were shown to be highly abundant in oligotrophic regions of the North Atlantic, forming about one-half of the total bacterial community in the Sargasso Sea (Campbell et al. 2008). The role of PRs in marine bacteria is still enigmatic. In the flavobacterium Dokdonia sp. strain MED134, PR provides energy for growth (Gómez-Consarnau et al. 2007). In contrast, no growth stimulation by light was observed in the SAR11 strain HTCC1062 (Giovannoni et al. 2005a). The second group of marine bacteria utilizing light was reported from the equatorial Pacific by Kolber et al. (2000). These organisms, so-called aerobic anoxygenic phototrophs (AAPs), were first described from the Bay of Tokyo in the 1970s by Harashima et al. (1978) and Shiba et al. (1979). AAPs contain BChl $a$ as a main light harvesting pigment, but in contrast to purple non-sulfur photosynthetic bacteria, these bacteria are obligate aerobes requiring oxygen for growth (Yurkov \& Beatty 1998).

In his first study, Kolber et al. (2000) speculated that the ability to utilize light might be beneficial especially in nutrient-poor marine environments. However, later studies have shown that AAPs are also abundant in eutrophic marine environments, such as the Baltic Sea (Koblížek et al. 2005, Mašín et al. 2006) or the Yangtze Estuary (Zhang \& Jiao 2007). Clearly, the capacity to harvest light provides an abundant source of metabolic energy. In fully photosynthetic (autotrophic) organisms, this energy is used for inorganic carbon assimilation. However, carbon fixation activity in AAPs is negligible (Kobližzek et al. 2003). AAPs seem to possess a 
photoheterotrophic metabolism, as they require the supply of an organic carbon substrate and light serves only as an additional source of energy. This ability probably helps AAPs to utilize the available carbon sources more economically, which might be beneficial under carbon-limiting conditions.

A lot of controversy was stirred by the first contradictory reports regarding the abundance of AAPs. The first study using infra-red epifluorescence microscopy suggested that AAPs formed $11 \%$ of the total bacterial community in the northeast Pacific Kolber et al. (2001). This number was questioned by Schwalbach \& Fuhrman (2005), claiming that the fraction of AAP bacteria was much smaller. Subsequent studies showed that AAP abundances may vary greatly. Today, it seems that AAPs are more abundant in shelf and coastal areas than in the open ocean. In spite of large differences, AAPs typically constitute only a small percentage ( 2 to $4 \%$ ) of total prokaryotes (Cottrell et al. 2006, Mašín et al. 2006, Sieracki et al. 2006, Jiao et al. 2007). As pointed out by Sieracki et al. (2006) and confirmed in subsequent studies, AAP bacteria are on average larger than regular heterotrophic bacteria. This means that, on a carbon basis, AAPs contribute more to the bacterioplankton biomass than it would appear from cell numbers alone.

Almost nothing is known about the dynamics of AAPs and their role in marine biogeochemical cycles. It has been suggested that $\mathrm{BChl}$ a can be used as a natural in situ tracer, as its decay during the day reflects AAP mortality (Koblížek et al. 2005). Under stable, steady-state conditions, mortality rates are equal to growth rates of AAP bacteria. Using this approach, it has been found that AAP bacteria in the Atlantic oligotrophic gyres grow at rates of about 1 cell division $\mathrm{d}^{-1}$. In more productive marine regions, such as zones of equatorial upwelling or the North Atlantic, AAPs may grow at rates of up to 3 cell divisions $\mathrm{d}^{-1}$ (Koblížek et al. 2007). This is much higher than current growth rate estimates for the total bacterial community. Thus, in spite of their lower abundance, AAPs appear to be a very dynamic part of marine microbial communities and to contribute significantly to organic carbon production and cycling in the upper ocean.

What the main factors affecting AAP distribution are is an open question. Obviously, phototrophic bacteria are only present in the illuminated euphotic zone of the oceans. Other factors, such as nutrient availability and grazing pressure, also have to play their role. In addition, some AAP bacteria might actively regulate their light-harvesting apparatus by switching it off when it is not needed. Clearly, further research on the physiology and metabolism of photoheterotrophic bacteria is necessary. Laboratory experiments with isolated strains might help to answer questions regarding their role in the marine carbon cycle, which may significantly differ between dark and light conditions when heterotrophic respiration (oxidative phosphorylarion) is supplemented by photosynthetically derived energy (photophosphorylation).

\section{DEEP OCEAN CHEMOAUTOTROPHY AS A SOURCE OF CARBON AND ENERGY FOR BACTERIA}

Until very recently, chemoautotrophy in the pelagic oxygenated realm of the ocean has been thought to be largely restricted to the nitrifying bacterial community in the mesopelagic waters and to the hydrothermal vent prokaryotic communities (Southward 1987, Ward 2000). With the notion that Crenarchaeota constitute a major portion of the prokaryotic community in the meso- and bathypelagic ocean (Karner et al. 2001, Teira et al. 2006) and the wide-spread occurrence of the archaeal amoA gene encoding the subunitA of the ammonia monooxygenase, a key enzyme in the oxidation of ammonia (Francis et al. 2005, Schleper et al. 2005, Wuchter et al. 2006), it became evident that prokaryotic chemoautotrophy in the dark ocean is largely mediated by Archaea (Herndl et al. 2005). This novel archaeal pathway in the nitrogen cycling is not restricted to the marine environment, but has also been reported for soil prokaryotes (Leininger et al. 2006). In both the open ocean and in soil, archaeal nitrification genes are at least 10 times more abundant than those of bacteria (Leininger et al. 2006, Wuchter et al. 2006). As nitrifying prokaryotes use inorganic carbon as a carbon source, the nitrifying prokaryotes, and particularly Crenarchaeota, represent a major source of newly synthesized organic carbon, i.e. an organic carbon source not transformed from phytoplankton (Ingalls et al. 2006).

While the potential of heterotrophic bacterial inorganic carbon utilization is well known from laboratory studies as anaplerotic metabolism (Gottschalk 1986), its significance in the marine environment should be rather limited, as the potential contribution to organic carbon synthesis of this pathway declines with the availability of sugars. Since deep-ocean bacteria are generally limited by the availability of organic carbon, it can be deduced with reasonable certainty that the anaplerotic metabolism of heterotrophic bacteria is only of minor importance. In contrast, deep-water chemoautotrophy by prokaryotes has not received adequate attention and has only sporadically been measured, but recent data suggest that it might be far more important than hitherto assumed (Herndl et al. 2005, Ingalls et al. 2006). While our knowledge of the spatial distribution and magnitude of carbon fixation in 
the oxygenated dark realm, comprising ca. $75 \%$ of the global ocean's volume, is rather rudimentary, inorganic carbon fixation in oxygen minimum zones has received far more attention, although it comprises only $0.1 \%$ of the ocean's volume (Taylor et al. 2001, Hannig et al. 2007, Lam et al. 2007).

Inorganic carbon fixation in the oxygenated aphotic water column of the North Atlantic has been determined by Herndl et al. (2005) and more recently by T. Reinthaler et al. (unpubl.). Integrated over the mesoand bathypelagic water column, prokaryotic inorganic carbon fixation in the open waters of the North Atlantic amounts to about $1 \mathrm{mmol} \mathrm{C} \mathrm{m}^{-2} \mathrm{~d}^{-1}$ (Herndl et al. 2005), compared to phytoplankton production of about $30 \mathrm{mmol} \mathrm{C} \mathrm{m}^{-2} \mathrm{~d}^{-1}$ (Sathyendranath et al. 1995). Thus, deep-water prokaryotic carbon fixation only amounts to ca. $3 \%$ of the primary production in the euphotic layer; however, $70 \%$ of this primary production is, on average, remineralized in the euphotic layer, with only ca. $30 \%$ entering the dark ocean (Berger et al. 1988, Antia et al. 2001). Hence, prokaryotic carbon fixation in the dark realm of the North Atlantic amounts to ca. $10 \%$ of the exported primary production. While the reactivity of the exported primary production declines with depth as a consequence of heterotrophic reworking, as indicated by the generally declining microbial activity with depth and diagenetic status of DOM, prokaryotic chemoautotrophy represents a source of newly fixed carbon in the deep ocean. Therefore, it might be a far more important carbon source for the deep-water microbial food web than hitherto assumed.

Pelagic prokaryotic chemoautotrophy increases with decreasing oxygen concentrations in the water column (Taylor et al. 2001, Hannig et al. 2007, Lam et al. 2007, Woebken et al. 2007). Consequently, highest pelagic prokaryotic carbon fixation rates have been reported for suboxic and anoxic water bodies such as the Black Sea, the Cariaco Basin and the twilight zones of upwelling areas (Taylor et al. 2001, Kuypers et al. 2005, Hamersley et al. 2007). By the end of the century, a loss of ca. $25 \%$ of the current oxygen content of the global ocean is predicted to occur due to changes in thermohaline circulation patterns and the accompanied warming and increased stratification (Bopp et al. 2002). This also implies that areas with suboxic conditions will increase in the future, with substantial consequences for the global nitrogen cycle as currently 30 to $50 \%$ of nitrogen-loss in the global ocean is mediated in the oxygen minimum zones (Francis et al. 2007). The predicted spread of oxygen minimum zones will lead to increasing prokaryotic chemoautotrophy, particularly in the mesopelagic waters of the global ocean. Hence, it is likely that deep-water pelagic food webs might be based on prokaryotic chemoautotrophy to a larger extent in the future ocean than at present.
Therefore, we need to include deep-water carbon fixation into general oceanic carbon flux models in order to allow better forecasting of future trends in oceanic carbon cycling.

\section{NOVEL PERSPECTIVES ON CARBON CYCLING FROM GENOMICS}

Although a relatively comprehensive inventory of the phylogenetic diversity of aquatic microorganisms has been achieved in the last decades, understanding the role of specific microorganisms (i.e. diversity) in particular biogeochemical processes (i.e. function) remains a great challenge. Analysis of genomic material is now contributing to the understanding of this linkage between biodiversity and ecosystem functioning. Recent advances in marine genomics and metagenomics have provided tremendous insights into the diversity of metabolic pathways and physiologies found in marine microbes, some of which were completely unexpected. For example, the potential for PR phototrophy in the surface ocean was discovered through the analysis of genomic fragments from marine bacterioplankton (Béjà et al. 2000, 2001). At the same time, an unforeseen abundance of marine AAPs was revealed (Kolber et al. 2000, 2001). Subsequently, experiments guided by the genome analysis of the PR-containing Flavobacteria isolate Dokdonia sp. MED134 showed that PR phototrophy could indeed provide critical amounts of energy from sunlight to support growth (Gómez-Consarnau et al. 2007). Considering the abundance of PR genes (Venter et al. 2004, Campbell et al. 2008) and AAPs (see section 'Role of aerobic anoxygenic phototrophs in the marine carbon cycle' above) in marine surface waters, it would be intriguing to determine how the potential for photoheterotrophy is realized, and how this affects carbon and energy fluxes in the ocean.

The first analyses of marine cyanobacterial genomes provided explanations for divergent patterns of depth distribution of ubiquitous primary producers (Dufresne et al. 2003, Palenik et al. 2003, Rocap et al. 2003). The first complete genome sequence of a marine 'heterotrophic' bacterioplankton species, Silicibacter pomeroyii, a member of the abundant Roseobacter clade, showed that it uses inorganic compounds like carbon monoxide and sulphide at concentrations found in the oceans to supplement heterotrophy (i.e. they are lithoheterotrophs, Moran et al. 2004). Genome analysis of Pelagibacter ubique in the SAR11 clade, one of the principal bacterial components in the sea, revealed the smallest genome known for a free-living microorganism, also containing the PR gene (Giovannoni et al. $2005 a, b)$. Very recent reports on genomic adaptations 
to life in the marine environment include the characterization of Alpha- and Gammaproteobacteria capable of aerobic anoxygenic photosynthesis (Fuchs et al. 2007, Swingley et al. 2007), the discovery of polymer degradation potential and life on particles among Flavobacteria (Bauer et al. 2006), and comparisons of the mechanisms to derive organic and inorganic nutrients from phytoplankton among marine Roseobacter (Moran et al. 2007). At the same time, large-scale environmental genome shotgun sequencing has provided marine microbial ecologists with challenging amounts of genetic and genomic information to explore (Venter et al. 2004, Rusch et al. 2007). Experimental metagenomics (Mou et al. 2008) contributes to matching ecological functions and bacterial diversity. As a consequence of studies such as those mentioned above, our perception of ocean functioning, and the microbes responsible for these functions, is rapidly becoming more richly facetted. This will become even more complex when single-cell genomics of isolated cells (Stepanauskas \& Sieracki 2007) becomes more common.

The studies mentioned here have generated new hypotheses on the genetic, metabolic and physiological capabilities of marine bacteria that have consequences for our understanding of their ecological role and the evolution of microbial communities. The hypotheses presented are now amenable to experimental studies and verification both in pure cultures and in situ. Advances in single-cell techniques, in combination with specified bulk measurements, are likely to provide the tools for such in situ studies (e.g. uptake of radiolabelled substrates combined with FISH). Detailed experimental characterization of factors (e.g. DOC or inorganic nutrient availability) that regulate growth and survival in distinct cultured bacteria will also be a fruitful approach to understanding the role of marine microbes, in particular if model organisms representing ubiquitous bacteria can be investigated (Giovannoni \& Stingl 2007). Improvements in culturing techniques, allowing the maintenance of the so far uncultivated majority of prokaryotes in the laboratory, will be an important task (Stingl et al. 2007). Evidently, the ultimate goal is to learn how widespread different metabolisms are in the sea and how they affect estimates of carbon, nutrient and energy flows.

At present, the bulk of knowledge about genes and their function used for annotating DNA sequences in metagenomic or genomic material is derived from easily cultured bacteria (most of which are primarily of clinical importance, e.g. Escherichia coli, Haemophilus influenzae and Yersinia pestis). This implies that there are genes of direct ecological interest that are conserved among cultured and uncultured marine bacteria. Future studies will show whether such genetic con- servation also applies to the conservation of enzyme properties and other protein functions. If so, studying and experimenting with 'user-friendly' bacteria will signify a huge leap forward in understanding ocean biogeochemistry. In other words, maybe genome analyses of cultured marine bacteria, even though they may be relatively rare components of bacterioplankton communities, could provide crucial insights into the physiologies governing fluxes of carbon and energy in the sea. In particular, comparative studies of genomes of closely related or more distant bacteria could reveal adaptations to life in the ocean, and subsequent analysis of the regulation of relevant genes involved in carbon-cycling under contrasting environmental conditions would be important.

\section{REFINED FUNCTIONAL AND REGIONAL RESOLUTION}

Many studies have been carried out over the last $20 \mathrm{yr}$, often in international programs like the Joint Global Ocean Flux Study (JGOFS), which assessed biomass production, respiration and growth dynamics of heterotrophic bacterioplankton in various oceanic and neritic regions of the major oceans. Despite methodological shortcomings such as those outlined in the previous sections, these studies provided a solid basis for the general understanding of the role of bacterioplankton in carbon flux in these ecosystems, as well as their constraints through the supply of substrate derived from phytoplankton primary production, growth limitation by organic carbon and other elements, and mortality losses due to protozoan grazing and virus infection (del Giorgio \& Cole 2000, Ducklow 2000, Doney \& Ducklow 2006). Today, we have a rather solid general knowledge of the fraction and range of phytoplankton primary production processed via bacterioplankton biomass production and respiration. The findings provide evidence that, in the mixed layer of cold regions like the Southern Ocean and the Arctic Ocean, a smaller fraction is bound in bacterioplankton biomass production than in warmer oceans where the microbial loop is relatively more important. In the former systems, which have a relatively higher sinking flux, more phytoplankton biomass is transferred below the mixed layer. Furthermore, there is evidence that the fraction of primary production respired by the bacterioplankton is enhanced in oligotrophic relative to more nutrient-rich regions, i.e. the bacterial growth efficiency is lower in oligotrophic systems. It appears that these patterns relate more to general characteristics of these ecosystems like the trophic state, the structure of the food web, and temperature, rather than to specific regional features such as the central gyres of 
the Atlantic vs. Pacific, the Peru vs. the Benguela upwelling, or coastal regions of the eastern vs. the western Atlantic.

Since the beginning of this millennium, work has intensified with refined culture-dependent and -independent methods to unveil the composition and the phylogenetic diversity of prokaryotic communities in marine systems (Giovannoni \& Rappé 2000). It has been shown that some prokaryotes, such as the SAR11 clade (Morris et al. 2002), occur globally, whereas others, like the RCA (Roseobacter clade affiliated) phylogenetic cluster, exhibit distinct distribution patterns and appear to reflect features of distinct marine biomes or even regional systems (Selje et al. 2004, Pommier et al. 2005, 2007). Cyanobacterial lineages also distribute differentially across marine biomes (Zwirglmaier et al. 2008). In fact, analysis of the metagenomic libraries of samples from the northwest Atlantic and eastern tropical Pacific 'Sorcerer II' global ocean sampling expedition revealed distinct regional patterns of the phylogenetic diversity (richness) of the prokaryotic communities (Rusch et al. 2007). Evidence is accumulating that the diversity of prokaryotic communities decreases from the tropics to polar marine systems, following general ecological rules (Pommier et al. 2007). However, we still know rather little about the quantitative occurrence and even less about the specific functional significance of distinct major and key players of the prokaryotic communities in various regions of the oceans. Metagenomic and genomic analyses of some key players may reveal their genetic potential, e.g. on their energy generation, and thus generate hypotheses on their ambient functional significance that can be tested in a given ecosystem.

Similarly, we know of vertical partitioning of bacterial assemblages along gradients of energy and nutrient availability (Field et al. 1997, DeLong et al. 2006), this partitioning being at a smaller scale than the horizontal partitioning (e.g. Acinas et al. 1997). Single-cell analysis techniques, such as the combination of microautoradiography with FISH (MAR-FISH) or stable isotope probing (SIP) can be used to describe the specificities of such vertical organizations (e.g. Teira et al. 2006, Varela et al. 2008).

For a better understanding of how prokaryotic communities process organic matter and its major elemental constituents in distinct regions of the major oceans, we need to identify the distinct metabolic pathways and quantify the flux rates of major constituents of the organic matter as well as the key players.

Aiming at a more refined understanding of the microbial trophodynamics in various marine pelagic systems, we should examine functional as well as structural microbial features of regional systems in various oceans more specifically. We need to integrate our knowledge on organic matter cycling with the emerging findings on the structure and functional diversity of prokaryotic communities in these systems and develop analytical and molecular tools to achieve these aims. For example, would it be interesting to know how microbial trophodynamics (and the constraints imposed by nutrient supply, nutrient limitation, and temperature) of the prokaryotic community of the Peru upwelling contrast with the California Current and the Benguela upwelling, or whether and how these features differ in the central gyres of the North and South Pacific, Atlantic or in various coastal regions of the Atlantic, Pacific or Indian Oceans? Should our aim be to attribute the major pathways of organic matter fluxes in these systems and their temporal development to relevant representatives of the prokaryotic communities? Knowing these features, we can start addressing specific questions of a marine microbial biogeography and eventually extend the ecological geography of the sea from phytoplankton and zooplankton (Longhurst 1998) to the bacterio-and archaeoplankton, and comprehensively characterize the marine biomes with respect to their structural and functional prokaryotic properties.

\section{MODELING CARBON FLOW THROUGH OCEANIC BACTERIA}

The first modern models of marine ecosystems used nitrogen as the currency and included phytoplankton and zooplankton as state variables (hence $\mathrm{P}-\mathrm{Z}-\mathrm{N}$ models), but lacked a bacterial compartment. Carbon flows were inferred via fixed element (Redfield) ratios. Steele (1974) included bacteria as part of the benthic community decomposing sedimenting fecal matter, but noted that data were insufficient to devise a valid water column component. In the same year, Pomeroy (1974) outlined a qualitative, conceptual model of oceanic food webs including bacterial recovery of DOM and predation by protozoans - the first recognition of the microbial loop, as it was later christened by Azam et al. (1983).

Williams (1981) provided a seminal and quantitative analysis showing how the microbial loop could coexist in a herbivore-dominated food web. The Fasham model (Fasham et al. 1990) formed the basis of the first basin-scale coupling of ocean circulation, plankton dynamics and nitrogen biogeochemistry (Fasham et al. 1993, Sarmiento et al. 1993). Subsequently, Thingstad et al. $(1997,1999)$ provided more detailed analyses and focused on the interplay of phosphorus limitation and bacterivory as master variables regulating carbon flows. Recent, highly ambitious efforts incorporating the concept of functional groups included heterotro- 
phic bacteria (Le Quéré et al. 2005), leading Anderson (2005) to question if we as microbial ecologists had sufficient understanding and data to create detailed models of bacterial processes (or even the biomass variability) in the oceans - the same issue addressed in passing by Steele 35 yr ago.

The initial benefits gained from modeling marine bacteria were 2-fold. The first, simple flow models (Vézina \& Platt 1988, Ducklow et al. 1989) showed that new findings of higher bacterial biomass and production were compatible and consistent with other information and concepts about the functioning of marine plankton systems. However, carbon-based estimates of BP in most of these models were unconstrained, either because they were single-currency (carbon-only) models or models with carbon and nitrogen related by invariant stoichiometric ratios (Kirchman et al. 1993). More realistic formulations of multielement nutrition are important for several reasons. As Thingstad et al. (1997) pointed out, bacterial growth may be limited by some nutrient other than carbon or nitrogen. Even if several different nutrients are modeled, fixed (Redfield) ratios are inappropriate since the elemental composition of bacteria differ markedly from phytoplankton (Goldman et al. 1987). Extracellular release of DOM by phytoplankton is also dependent on the degree and form of nutrient limitation. Both the supply of and demand for bacterial resources depends on fluctuating ratios of $\mathrm{C}, \mathrm{N}, \mathrm{P}$ and probably micronutrients (Church et al. 2000). Finally, Alonso-Sáez et al. (2007) showed that the relationship between BP and protein synthesis varied across trophic states. All these observations indicate the need for more sophisticated formulations of nutrient fluxes through the microbial food web.

Given the uncertainties in deriving empirical production estimates described herein, an independent and objective approach is needed to model realistic bacterial utilization and BP rates, consistent with observations of other plankton processes such as primary production, grazing and DOC release (Morán et al. 2002). One approach is the combination of flexiblestoichiometry, multielement $(C, N, P)$ models of plankton biogeochemistry (Y. Luo \& H. Ducklow unpubl.), with data assimilation (Friedrichs 2001, Friedrichs et al. 2007). Without objective means of model-data comparison and parameter adjustment, the estimates of carbon fluxes generated by models are unconstrained and provide no measure of the overall agreement between modeled and observed fluxes. New, more detailed models generate specific hypotheses for testing, but cannot substitute more reliable and precise measurements. In the end, even new, more sophisticated model approaches are still only as good as the data and concepts on which they are based.
Observations and experiments suggest other issues requiring resolution. The formerly accepted constancy in the percentage of primary production released as extracellular DOM (Baines \& Pace 1991) does not hold, and oligotrophic planktonic ecosystems release a higher percentage of the total primary production than nutrient-richer ecosystems. For example, Teira et al. (2001) and Morán et al. (2002) documented release of up to $35 \%$. Heterotrophic bacteria can also generate DOM by processes such as viral lysis or autolysis. Furthermore, capsular materials (Stoderegger \& Herndl 1998, 2001) and ectoenzymes produced and excreted by bacteria can be considered as 'dissolved bacterial production' (dBP). Stoderegger \& Herndl (1998, 2001) calculated that this process could amount to $25 \%$ of $\mathrm{BR}$. If $\mathrm{BR}$ is ca. twice the $\mathrm{BP}$ in most oceanic environments, it means that dBP could account for up to $50 \%$ BP! Kawasaki \& Benner (2006) estimated the percentages of extracellular release of DOM by bacteria to range from 14 to $31 \%$, indicating that $\mathrm{BP}$ and $\mathrm{BGE}$ are underestimated when only cellular carbon is measured. Kaiser \& Benner (2008) calculated that dBP may amount to $25 \%$ of particulate and dissolved organic carbon (POC and DOC) and $50 \%$ of particulate and dissolved organic nitrogen (PON and DON). Such observations suggest the need for a more finely articulated model of DOM flows into, within and from the microbial food web (Fig. 1).

Above, we mostly considered resource supply to bacteria (bottom-up processes), but top-down pro-

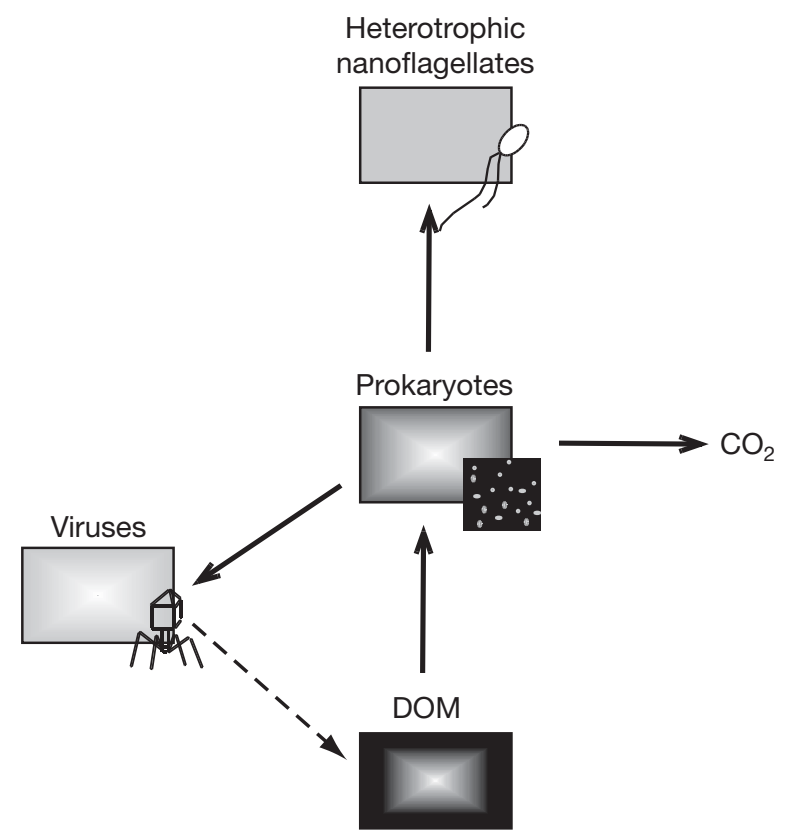

Fig. 1. A typical simplified view of the role of heterotrophic prokaryotes in the marine carbon cycle. Arrows indicate carbon pathways, including ingestion and excretion (solid arrows) or indirect carbon fluxes (dashed arrow) 
cesses need better representation as well. Our standard representation of the microbial food web in Fig. 1 shows just one type of carbon flow from bacteria to heterotrophic nanoflagellates. However, sometimes there is another, smaller type of flow to photosynthetic nanoflagellates. We have known for quite some time that photosynthetic ('plastidic') flagellates also feed on bacteria (Estep et al. 1986), but the combination of 2 recent results indicates that the primary carbon flow should probably go towards the plastidic flagellates, and smaller quantities (Fig. 2, small arrows) should go to the heterotrophic nanoflagellates. Recent estimates of the ratio of nonplastidic flagellates to total flagellates in various marine areas suggest that it is $5: 1$
(Jürgens \& Massana 2008), and one study in a coastal oligo-mesotrophic area showed that, year-round, 50\% of bacterial flux to heterotrophic flagellates goes through the photosynthetic, plastidic flagellates (Unrein et al. 2007). Mixotrophy, as developed in the previous sections, seems to be a general and widespread trophic strategy in the ocean, both for prokaryotes as well as microbial eukaryotes. Again, our models might be based too heavily on our preconceptions and established paradigms (Fig. 1), instead of being based on the data (Fig. 2).

The most important and valuable function of models is to provide explicit, objective descriptions of what we understand, and to reveal quantitatively what we do
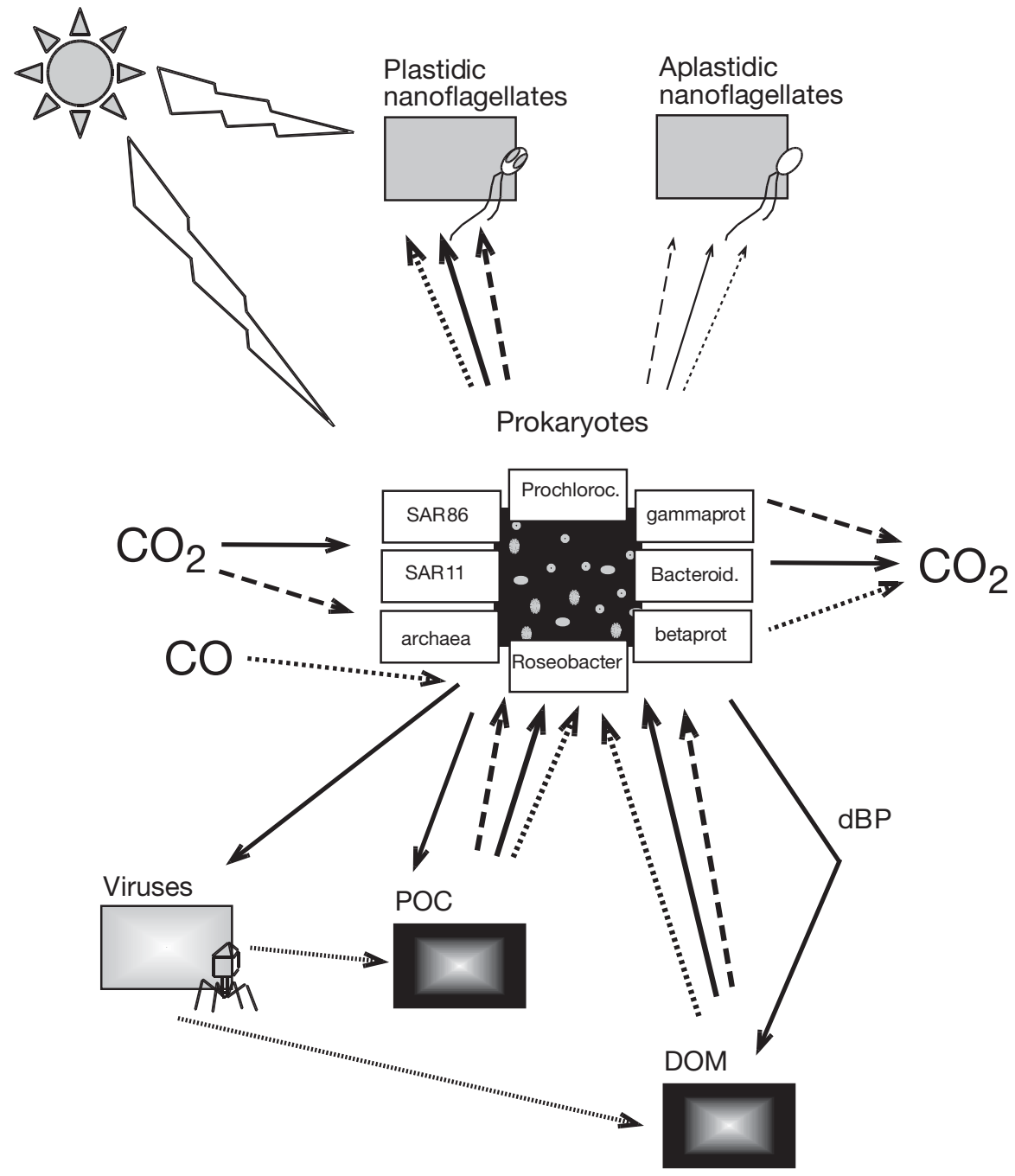

Fig. 2. A revised view of the role of heterotrophic prokaryotes in the marine carbon cycle, incorporating some of the issues considered in this article. It intends to illustrate that prokaryotes use not only organic carbon but also inorganic forms of carbon as well as light, that plastidic flagellates might play as important a role as that of heterotrophic flagellates in using prokarotic cells, and that dissolved organic carbon (DOC) can also be directly produced by bacteria (i.e. not mediated by viruses or grazers). The figure also illustrates, by using different types of lines, that the paths from the various types of carbon to the prokaryotes, and from them to the grazers and viruses, are most likely different in form and magnitude for each different type of prokaryote 
not. Clearly, models have helped us to understand elemental flows in the microbial food web and some of the factors controlling their magnitude and variability. Improved models - and improved understanding — will come from better model representations of nutrient limitation, extracellular release processes and predation.

All these issues arise from simple models of a bulk, undifferentiated 'bacterial' component of plankton ecosystems. In recent years, metagenomics has revealed a vast diversity of bacterial and archaeal 'species' and functional groups. The frontier of microbial modeling, and that of microbial ecology itself, is to understand and quantitatively describe the specific functions of these many bacterial types and their dynamics in natural environments (Doney et al. 2004, Follows et al. 2007).

\section{CONCLUSION}

It is possible that, at some point, the community of aquatic microbial ecologists might have gotten carried away by the beauty inherent in the discovery of hidden microbial diversity when techniques to analyze it at the 'species' or function level became available. In a way, this may have left some of our homework undone: constraining volume-to-carbon conversion factors, finding a real-time respiration method, understanding the changes in bacterial phyisology when a bottle is closed, determining the variability in leucine content, protein content and the respective factors in isolates of different types of organisms, to cite just a few.

At the same time, we know the role of different boxes in the model depicted in Fig. 2 relatively well, and we are able to discuss it and spot and highlight the points we do not understand. As several of the scientists present at the Faro Workshop put it, we certainly have advanced a lot since $20 \mathrm{yr}$ ago, and, in fact, the molecular and single-cell analysis techniques have helped very much.

Challenges for enthusiastic graduate students, however, are there and waiting.

Acknowledgements. We thank the organizers of the SAME 10 meeting for the nice environment and the very fruitful meeting. P. del Giorgio pushed us to write down our thoughts, and shared many with us. D. Kirchman commented on some of the issues raised, and C. Pedrós-Alió commented on one of the first drafts. J.M.G. and J.P. summarized and reported on our discussion. Our work was supported by the following grants: NSF grant 0217282 (H.D.), Spanish MEC grant MODIVUS (J.M.G.), the Swedish Science Council (J.P.), the IEO time-series RADIALES programme (X.A.G.M.), the Earth and Life Science Division of the Dutch Science Foundation, ARCHIMEDES project, \#835.20.023 (G.J.H.). Work of some of the authors was carried out within the frame of the 'Networks of Excellence' MarBef and EurOceans (6th FP of the EU).

\section{LITERATURE CITED}

Aas P, Lyons MM, Pledger R, Mitchell DL, Jeffrey WH (1996) Inhibition of bacterial activities by solar radiation in nearshore waters and the Gulf of Mexico. Aquat Microb Ecol 11:229-238

> Acinas SG, Rodríguez-Valera F, Pedrós-Alió C (1997) Spatial and temporal variation in marine bacterioplankton diversity as shown by RFLP fingerprinting of PCR amplified 16S rDNA. FEMS Microbiol Ecol 24:27-40

Acinas SG, Klepac-Ceraj V, Hunt DE, Pharino C, Ceraj I, Distel DL, Polz MF (2004) Fine-scale phylogenetic architecture of a complex bacterial community. Nature 430: $551-554$

Alonso-Sáez L, Gasol JM (2007) Seasonal variation in the contribution of different bacterial groups to the uptake of low molecular weight-compounds in NW Mediterranean coastal waters. Appl Environ Microbiol 73:3528-3535

Alonso-Sáez L, Gasol JM, Lefort T, Hofer J, Sommaruga R (2006) Effect of natural sunlight on bacterial activity and differential sensitivity of natural bacterioplankton groups in northwestern Mediterranean coastal waters. Appl Environ Microbiol 72:5806-5813

Alonso-Sáez L, Gasol JM, Arístegui J, Vilas JC and others (2007) Large-scale variability in surface bacterial carbon demand and growth efficiency in the subtropical northeast Atlantic Ocean. Limnol Oceanogr 52:533-546

Alonso-Sáez L, Vázquez-Domínguez E, Cardelús C, Pinhassi $J$ and others (2008) Factors controlling the year-round variability in carbon flux through bacteria in a coastal marine system. Ecosystems 11:397-409

Anderson TR (2005) Plankton functional type modelling: running before we can walk? J Plankton Res 27:1073-1081

Antia AN, Koeve W, Fischer G, Blanz T and others (2001) Basin-wide particulate carbon flux in the Atlantic Ocean: regional export patterns and potential for athmospheric $\mathrm{CO}_{2}$ sequestration. Global Biogeochem Cycles 15: $845-862$

- Arístegui J, Duarte CM, Gasol JM, Alonso-Sáez L (2005) Active mesopelagic prokaryotes support high respiration in the subtropical Northeast Atlantic Ocean. Geophys Res Lett 32:L03608

Azam F, Fenchel T, Field JG, Gray JS, Meyer-Reil LA, Thingstad F (1983) The ecological role of water-column microbes in the sea. Mar Ecol Prog Ser 10:257-263

Baines SB, Pace ML (1991) The production of dissolved organic matter by phytoplankton and its importance to bacteria: patterns across marine and freshwater systems. Limnol Oceanogr 36:1078-1090

Baldwin AJ, Moss JA, Pakulski JD, Catala P, Joux F, Jeffrey WH (2005) Microbial diversity in a Pacific Ocean transect from the Arctic to Antarctic circles. Aquat Microb Ecol 41:91-102

> Bauer M, Kube M, Teeling H, Richter M and others (2006) Whole genome analysis of the marine Bacteroidetes 'Gramella forsetii' reveals adaptations to degradation of polymeric organic matter. Environ Microbiol 8:2201-2213

Béjà O, Aravind L, Koonin EV, Suzuki MT and others (2000) Bacterial rhodopsin: evidence for a new type of phototrophy in the sea. Science 289:1902-1906

> Béjà O, Spudich EN, Spudich JL, Leclerc M, DeLong EF (2001) Proteorhodopsin phototrophy in the ocean. Nature 411:786-789

Benner R, Biddanda B (1998) Photochemical transformations of surface and deep marine dissolved organic matter: effects on bacterial growth. Limnol Oceanogr 43:1373-1378

Berger WH, Fischer K, Lai C, Wu G (1988) Ocean carbon flux: 
global maps of primary production and export production. In: Agegian CR (ed) Biogeochemical cycling and fluxes between the deep euphotic zone and other oceanic realms. NOAA Natl Undersea Res Prog 88-1, p 131-176

Bopp L, Le Quéré C, Heimann M, Manning AC, Monfray P (2002) Climate-induced oceanic oxygen fluxes: implications for the contemporary carbon budget. Global Biogeochem Cycles 16:1022

Briand E, Pringault O, Jacquet S, Torréton JP (2004) The use of oxygen microprobes to measure bacterial respiration for determining bacterioplankton growth eficiency. Limnol Oceanogr Methods 2:406-416

Campbell BJ, Waidner LA, Cottrell MT, Kirchman DL (2008) Abundant proteorhodopsin genes in the North Atlantic Ocean. Environ Microbiol 10:99-109

$>$ Church MJ, Hutchins DA, Ducklow HW (2000) Limitation of bacterial growth by dissolved organic matter and iron in the Southern Ocean. Appl Environ Microbiol 66:455-466

Church MJ, Ducklow HW, Karl DA (2004) Light dependence of [H-3]leucine incorporation in the oligotrophic North Pacific ocean. Appl Environ Microbiol 70:4079-4087

Church MJ, Ducklow HW, Letelier RM, Karl DM (2006) Temporal and vertical dynamics in picoplankton photoheterotrophic production in the subtropical North Pacific Ocean. Aquat Microb Ecol 45:41-53

Cole JJ, Caraco NF, Strayer DL, Ochs C, Nolan S (1989) A detailed organic carbon budget as an ecosystem-level calibration of bacterial respiration in an oligotrophic lake during midsummer. Limnol Oceanogr 34:286-296

> Cottrell MT, Kirchman DL (2000) Natural assemblages of marine proteobacteria and members of the CytophagaFlavobacter cluster consuming low- and high-molecularweight dissolved organic matter. Appl Environ Microbiol 66:1692-1697

Cottrell MT, Mannino A, Kirchman DL (2006) Aerobic anoxygenic phototrophic bacteria in the Mid-Atlantic Bight and the North Pacific Gyre. Appl Environ Microbiol 72: 557-564

del Giorgio PA, Cole JJ (1998) Bacterial growth efficiency in natural aquatic systems. Annu Rev Ecol Syst 29:503-541

del Giorgio PA, Cole JJ (2000) Bacterial energetics and growth efficiency. In: Kirchman DL (ed) Microbial ecology of the oceans. Wiley-Liss, New York, p 289-326

del Giorgio PA, Davis J (2003). Patterns in dissolved organic matter lability and consumption across aquatic ecosystems. In: Findlay S (ed) Aquatic ecosystems: interactivity of dissolved organic matter. Elsevier Science, San Diego, CA, p 399-424

DeLong EF (2005) Microbial community genomics in the ocean. Nat Rev Microbiol 3:459-468

DeLong EF, Karl DM (2005) Genomic perspectives in microbial oceanography. Nature 437:336-342

DeLong EF, Preston CM, Mincer T, Rich V and others (2006) Community genomics among stratified microbial assemblages in the ocean's interior. Science 311:496-503

> Doney SC, Ducklow HW (2006) A decade of synthesis and modeling in the US Joint Global Ocean Flux Study. DeepSea Res II 53:451-458

Doney SC, Abbott MR, Cullen JJ, Karl DM, Rothstein L (2004) From genes to ecosystems: the ocean's new frontier. Front Ecol Environ 2:457-466

Ducklow HW (2000) Bacterial production and biomass in the oceans. In: Kirchman DL (ed) Microbial ecology of the oceans. Wiley-Liss, New York, p 85-120

Ducklow HW, Fasham MJR, Vézina AF (1989) Derivation and analysis of flow networks for open ocean plankton systems. In: Wulff F, Field JG, Mann KH (eds) Network analy- sis in marine ecology: methods and applications. Springer, Berlin, p 159-205

Ducklow HW, Dickson ML, Kirchman DL, Steward G, Orchardo J, Marra J, Azam F (2000) Constraining bacterial production, conversion efficiency and respiration in the Ross Sea, Antarctica, January-February, 1997. Deep-Sea Res II 47:3227-3247

Dufresne A, Salanoubat M, Partensky F, Artiguenave F and others (2003) Genome sequence of the cyanobacterium Prochlorococcus marinus SS120, a nearly minimal oxyphototrophic genome. Proc Natl Acad Sci USA 100: 10020-10025

Estep KW, Davis PG, Keller MD, Sieburth JMcN (1986) How important are oceanic algal nanoflagellates in bacterivory? Limnol Oceanogr 31:646-650

Fasham MJR, Ducklow HW, McKelvie SM (1990) A nitrogenbased model of plankton dynamics in the oceanic mixed layer. J Mar Res 48:591-639

Fasham MJR, Sarmiento JL, Slater RD, Ducklow HW, Williams R (1993) A seasonal 3-dimensional ecosystem model of nitrogen cycling in the North Atlantic euphotic zone: a comparison of the model results with observations from Bermuda Station 'S' and OWS 'India'. Global Biogeochem Cycles 7:379-416

Fenchel T (2001) Marine bugs and carbon flow. Science 292:2444-2445

Field KG, Gordon D, Wright T, Rappé M, Urbach E, Vergin K, Giovannoni SJ (1997) Diversity and depth-specific distribution of SAR11 cluster rRNA genes from marine planktonic bacteria. Appl Environ Microbiol 63:63-70

Follows MJ, Dutkiewicz S, Grant S, Chisholm SW (2007) Emergent biogeography of microbial communities in a model ocean. Science 315:1843-1846

Francis CA, Roberts KJ, Beman JM, Santoro AE, Oakley BB (2005) Ubiquity and diversity of ammonia-oxidizing archaea in water columns and sediments of the ocean. Proc Natl Acad Sci USA 102:14683-14688

- Francis CA, Beman JM, Kuypers MMM (2007) New processes and players in the nitrogen cycle: the microbial ecology of anaerobic and archaeal ammonia oxidation. ISME J $1: 19-27$

Friedrichs MAM (2001) Assimilation of JGOFS EqPac and SeaWiFS data into a marine ecosystem model of the central equatorial Pacific Ocean. Deep-Sea Res II 49: 289-319

> Friedrichs MAM, Dusenberry JA, Anderson LA, Armstrong R and others (2007) Assessment of skill and portability in regional marine biogeochemical models: the role of multiple planktonic groups. J Geophys Res 112:C08001

Fuchs BM, Zubkov MV, Sahm K, Burkill PH, Amann R (2000) Changes in community composition during dilution cultures of marine bacterioplankton as assessed by flow cytometric and molecular biological techniques. Environ Microbiol 2:191-201

Fuchs BM, Spring S, Teeling H, Quast C and others (2007) Characterization of a marine gammaproteobacterium capable of aerobic anoxygenic photosynthesis. Proc Natl Acad Sci USA 104:2891-2896

Fuhrman JA, Azam F (1980) Bacterioplankton secondary production estimates for coastal waters of British Columbia, Antarctica and California. Appl Environ Microbiol 39: 1085-1095

Fuhrman JA, Eppley RW, Hagström A, Azam F (1985) Diel variations in bacterioplankton, phytoplankton, and related parameters in the Southern California Bight. Mar Ecol Prog Ser 27:9-20

> Gasol JM, Morán XAG (1999) Effects of filtration on bacterial activity and picoplankton community structure as 
assessed by flow cytometry. Aquat Microb Ecol 16: 251-264

Gasol JM, del Giorgio PA, Massana R, Duarte CM (1995) Active versus inactive bacteria: size-dependence in a coastal marine plankton community. Mar Ecol Prog Ser 128:91-97

> Gasol JM, Doval MD, Pinhassi J, Calderón-Paz JI, GuixaBoixareu N, Vaqué D, Pedrós-Alió C (1998) Diel variations in bacterial heterotrophic activity and growth in the northwestern Mediterranean Sea. Mar Ecol Prog Ser 164: 107-124

Gattuso JP, Peduzzi S, Pizay MD, Tonolla M (2002) Changes in freshwater bacterial community composition during measurements of microbial and community respiration. J Plankton Res 24:1197-1206

Giovannoni SJ, Rappé M (2000) Evolution, diversity and molecular ecology of marine prokaryotes. In Kirchman DL (ed) Microbial ecology of the oceans. Wiley-Liss, New York, p 47-84

Giovannoni S, Stingl U (2007) The importance of culturing bacterioplankton in the 'omics' age. Nat Rev Microbiol 5:820-826

> Giovannoni SJ, Bibbs L, Cho JL, Stapels MD and others (2005a) Proteorhodopsin in the ubiquitous marine bacterium SAR11. Nature 438:82-85

Giovannoni SJ, Tripp HJ, Givan S, Podar M and others (2005b) Genome streamlining in a cosmopolitan oceanic bacterium. Science 309:1242-1245

Goldman JC, Caron DA, Dennett MR (1987) Regulation of gross growth efficiency and ammonium regeneration in bacteria by substrate C:N ratio. Limnol Oceanogr 32: 1239-1252

Gómez-Consarnau L, González JM, Coll-Lladó M, Gourdon P and others (2007) Light stimulates growth of proteorhodopsin-containing marine Flavobacteria. Nature 445: 210-213

Gottschalk G (1986) Bacterial metabolism. Springer, New York

Hamersley MR, Lavik G, Woebken D, Rattray JE and others (2007) Anaerobic ammonium oxidation in the Peruvian oxygen minimum zone. Limnol Oceanogr 52:923-933

Hannig M, Lavik G, Kuypers MMM, Woebken D, MartensHabbena W, Jürgens K (2007) Shift from denitrification to anammox inflow events in the central Baltic Sea. Limnol Oceanogr 52:1336-1345

Harashima K, Shiba T, Totsuka T, Simidu U, Taga N (1978) Occurence of bacteriochlorophyll $a$ in a strain of an aerobic heterotrophic bacterium. Agric Biol Chem 42: 1627-1628

Harris JRW, Stutt ED, Turley CM (2001) Carbon flux in the northwest Mediterranean estimated from microbial production. Deep-Sea Res I 48:2631-2644

> Henriques IS, Almeida A, Cunha A, Correia A (2004) Molecular sequence analysis of prokaryotic diversity in the middle and outer sections of the Portuguese estuary Ria de Aveiro. FEMS Microbiol Ecol 49:269-279

> Hernández KL, Quiñones RA, Daneri G, Helbling EW (2006) Effects of solar radiation on bacterioplankton production in the upwelling system off central-southern Chile. Mar Ecol Prog Ser 315:19-31

> Herndl GJ, Müller-Niklas G, Frick J (1993) Major role of ultraviolet-B in controlling bacterioplankton growth in the surface layer of the ocean. Nature 361:717-719

> Herndl GJ, Reinthaler T, Teira E, van Aken H, Veth C, Pernthaler A, Pernthaler J (2005) Contribution of Archaea to total prokaryotic production in the deep Atlantic Ocean. Appl Environ Microbiol 71:2303-2309
Ingalls AE, Shah SR, Hansman RL, Aluwihare LI, Santos GM, Druffel ERM, Pearson A (2006) Quantifying archaeal community autotrophy in the mesopelagic ocean using natural radiocarbon. Proc Natl Acad Sci USA 103:6442-6447

Jiao N, Zhang Y, Zeng Y, Hong N, Liu R, Chen F, Wang P (2007) Distinct distribution pattern of abundance and diversity of aerobic anoxygenic phototrophic bacteria in the global ocean. Environ Microbiol 9:3091-3099

Jürgens K, Massana R (2008) Protist grazing on marine bacterioplankon. In: Kirchman DL (ed) Microbial ecology of the oceans, 2nd edn. Wiley-Liss, New York, p 383-442

Kaiser K, Benner R (2008) Major bacterial contribution to the ocean reservoir of detrital organic carbon and nitrogen. Limnol Oceanogr 53:99-112

Karl DM (2002) Hidden in a sea of microbes. Nature 415:590-591

Karner MB, DeLong EF, Karl DM (2001) Archaeal dominance in the mesopelagic zone of the Pacific Ocean. Nature 409:507-510

Kawasaki N, Benner R (2006) Bacterial release of dissolved organic matter during cell growth and decline: molecular origin and composition. Limnol Oceanogr 51:2170-2180

Kiene RP, Linn LJ (1999) Filter-type and sample handling affect determination of organic substrate uptake by bacterioplankton. Aquat Microb Ecol 17:311-321

Kirchman DL, K'nees E, Hodson R (1985) Leucine incorporation and its potential as a measure of protein synthesis by bacteria in natural aquatic systems. Appl Environ Microbiol 49:599-607

Kirchman DL, Lancelot C, Fasham M, Legendre L, Radach G, Scott M (1993) Dissolved organic matter. In: Evans GT, Fasham MJR (eds) Towards a model of ocean biogeochemical processes. Springer, Berlin, p 209-225

Koblížek M, Béjà O, Bidigare RR, Christensen $\mathrm{S}$ and others (2003) Isolation and characterization of Erythrobacter sp. strains from the upper ocean. Arch Microbiol 180:327-338

Kobližek M, Ston-Egiert J, Sagan S, Kolber ZS (2005) Diel changes in bacteriochlorophyll a concentration suggest rapid bacterioplankton cycling in the Baltic Sea. FEMS Microbiol Ecol 51:353-361

Koblížek M, Mašín M, Ras J, Poulton AJ, Prášil O (2007) Rapid growth rates of aerobic anoxygenic phototrophs in the ocean. Environ Microbiol 9:2401-2406

Kolber ZS, Van Dover CL, Niederman RA, Falkowski PG (2000) Bacterial photosynthesis in surface waters of the open ocean. Nature 407:177-179

Kolber ZS, Plumley FG, Lang AS, Beatty JT and others (2001) Contribution of aerobic photoheterotrophic bacteria to the carbon cycle in the ocean. Science 292:2492-2495

Kuypers MMM, Lavik G, Woebken D, Schmid M, Fuchs BM, Jörgensen BB, Jetten MSM (2005) Massive nitrogen loss from the Benguela upwelling system through anaeorbic ammonium oxidation. Proc Natl Acad Sci USA 102: 6478-6483

> Lam P, Jensen MM, Lavik G, McGinnis DF and others (2007) Linking crenarchaeal and bacterial nitrification to anammox in the Black Sea. Proc Natl Acad Sci USA 104: 7104-7109

Leininger S, Ulrich T, Schloter M, Schwark L and others (2006) Archaea predominate among ammonia-oxidizing prokaryotes in soils. Nature 442:806-809

Lemée R, Rochelle-Newall E, van Wambeke F, Pizay MD, Rinaldi P, Gattuso JP (2002) Seasonal variation of bacterial production, respiration and growth efficiency in the open NW Mediterranean Sea. Aquat Microb Ecol 29:227-237

Le Quéré C, Harrison SP, Colin PI, Buitenhuis ET and others (2005) Ecosystem dynamics based on plankton functional 
types for global ocean biogeochemistry models. Glob Change Biol 11:2016-2040

Lindell MJ, Granéli W, Tranvik LJ (1995) Enhanced bacterial growth in response to photochemical transformation of dissolved organic matter. Limnol Oceanogr 40:195-199

Longhurst AR (1998) Ecological geography of the sea. Academic Press, San Diego, CA

López-Urrutia A, Morán XAG (2007) Resource limitation of bacterial production distorts the temperature dependence of oceanic carbon cycling. Ecology 88:817-822

Malmstrom RR, Cottrell MT, Elifantz H, Kirchman DL (2005) Biomass production and assimilation of dissolved organic matter by SAR11 bacteria in the Northwest Atlantic Ocean. Appl Environ Microbiol 71:2979-2986

Mašín M, Zdun A, Stoñ-Egiert J, Nausch M, Labrenz M, Moulisová V, Koblížek M (2006) Seasonal changes and diversity of aerobic anoxygenic phototrophs in the Baltic Sea. Aquat Microb Ecol 45:247-254

Massana R, Pedrós-Alió C, Casamayor EO, Gasol JM (2001) Changes in marine bacterioplankton phylogenetic composition during incubations designed to measure biogeochemically significant parameters. Limnol Oceanogr 46: 1181-1188

Michelou VK, Cottrell MT, Kirchman DL (2007) Light-stimulated bacterial production and amino acid assimilation by cyanobacteria and other microbes in the North Atlantic Ocean. Appl Environ Microbiol 73:5539-5546

Moran MA, Miller WL (2007) Resourceful heterotrophs make the most of light in the coastal ocean. Nat Rev Microbiol 5:792-800

Moran MA, Zepp RG (2000) UV radiation effects on microbes and microbial processes. In: Kirchman DL (ed) Microbial ecology of the oceans. Wiley-Liss, New York, p 201-228

- Moran MA, Buchan A, González JM, Heidelberg JF and others (2004) Genome sequence of Silicibacter pomeroyi reveals adaptations to the marine environment. Nature 432:910-913

Moran MA, Belas R, Schell MA, Gonzdlez JM and others (2007) Ecological genomics of marine roseobacters. Appl Environ Microbiol 73:4559-4569

> Morán XAG, Massana R, Gasol JM (2001) Light conditions affect the measurement of oceanic bacterial production via leucine uptake. Appl Environ Microbiol 67:3795-3801

Morán XAG, Estrada M, Gasol JM, Pedrós-Alió C (2002) Dissolved primary production and the strength of phytoplankton-bacterioplankton coupling in contrasting marine regions. Microb Ecol 44:217-223

- Morris RM, Rappe MS, Connon SA, Vergin KL, Siebold WA, Carlson CA, Giovannoni SJ (2002) SAR11 clade dominates ocean surface bacterioplankton communities. Nature 420: 806-810

Morris RM, Rappé MS, Urbach E, Connon SA, Giovanonni SJ (2004) Prevalence of the Chloroflexi-related SAR202 bacterioplankton cluster throughout the mesopelagic zone and deep ocean. Appl Environ Microbiol 70:2836-2842

Mou X, Sun S, Edwards RA, Hodson RE, Moran MA (2008) Bacterial carbon processing by generalist species in the coastal ocean. Nature 451:708-711

Nelson CE, Carlson CA (2005) A nonradioactive assay of bacterial productivity optimized for oligotrophic pelagic environments. Limnol Oceanogr Methods 3:211-220

Obernosterer I, Reitner B, Herndl GJ (1999) Contrasting effects of solar radiation on dissolved organic matter and its bioavailability to marine bacterioplankton. Limnol Oceanogr 44:1645-1654

Pace NR (2006) Time for a change. Nature 441:289

Pakulski JD, Baldwin A, Dean AL, Durkin S and others (2007)
Responses of heterotrophic bacteria to solar irradiance in the eastern Pacific Ocean. Aquat Microb Ecol 47:153-162

Palenik B, Dufresne A, Partensky F, Waterbury J and others (2003) The genome of a motile marine Synechococcus. Nature 424:1037-1042

- Pausz C, Herndl GJ (1999) Role of ultraviolet radiation on phytoplankton extracellular release and its subsequent utilization by marine bacterioplankton. Aquat Microb Ecol 18:85-93

Pinhassi J, Winding A, Binnerup S, Zweifel UL, Riemann B, Hagström $\AA$ (2003) Spatial variability in bacterioplankton community composition at the Skagerrak-Kattegat front. Mar Ecol Prog Ser 255:1-13

> Pomeroy LR (1974) The oceans food web, a changing paradigm. Bioscience 24:499-504

> Pommier T, Pinhassi J, Hagström ^ (2005) Biogeographic analysis of ribosomal RNA clusters from marine bacterioplankton. Aquat Microb Ecol 41:79-89

Pommier T, Canbäck B, Riemann L, Boström KH and others (2007) Global patterns of diversity and community structure in marine bacterioplankton. Mol Ecol 16:867-880

Pringault O, Tassas V, Rochelle-Newall E (2007) Consequences of respiration in the light on the determination of production in pelagic systems. Biogeosciences 4:105-114

Pulido-Villena E, Reche I (2003) Exploring bacterioplankton growth and protein synthesis to determine conversion factors across a gradient of dissolved organic matter. Microb Ecol 46:33-42

Rappé MS, Connon SA, Vergin KL, Giovanonni SJ (2002) Cultivation of the ubiquitous SAR11 marine bacterioplankton clade. Nature 418:630-633

Reinthaler T, Herndl GJ (2005) Seasonal dynamics of bacterial growth efficiencies in relation to phytoplankton in the Southern North Sea. Aquat Microb Ecol 39:7-16

Reinthaler $\mathrm{T}$, van Aken $\mathrm{H}$, Veth $\mathrm{C}$, Arístegui J and others (2006) Prokaryotic respiration and production in the mesoand bathypelagic realm of the eastern and western North Atlantic basin. Limnol Oceanogr 51:1262-1273

- Riemann L, Leitet C, Pommier T, Simu K, Holmfeldt K, Larsson U, Hagström A (2008) The native bacterioplankton community in the Central Baltic Sea is influenced by frehwater bacterial species. Appl Environ Microbiol 74: 503-515

Rivkin RB, Legendre L (2001) Biogenic carbon cycling in the ocean: effects of microbial respiration. Science 291: $2398-2400$

> Rocap G, Larimer FW, Post AF, Chisholm SW (2003) Genome divergence in two Prochlorococcus ecotypes reflects oceanic niche differentiation. Nature 424:1042-1047

> Rusch DB, Halpern AL, Sutton G, Heidelberg KB and others (2007) The Sorcerer II global ocean sampling expedition: Northwest Atlantic through eastern Tropical Pacific. PLoS Biol 5:398-431

> Sarmiento JL, Slater RD, Fasham MJR, Ducklow HW, Toggweiler JR, Evans GT (1993) A seasonal three-dimensional ecosystem model of nitrogen cycling in the North Atlantic euphotic zone. Global Biogeochem Cycles 7:417-450

Sathyendranath S, Longhurst A, Caverhill CM, Platt T (1995) Regionally and seasonally differentiated primary production in the North Atlantic. Deep-Sea Res I 42:1773-1802

> Schleper C, Jurgens G, Jonuscheit M (2005) Genomic studies of uncultivated Archaea. Nat Rev Microbiol 3:479-488

Schwalbach MS, Fuhrman JA (2005) Wide-ranging abundances of aerobic anoxygenic phototrophic bacteria in the world ocean revealed by epifluorescence microscopy and quantitative PCR. Limnol Oceanogr 50:620-628

Selje N, Simon M, Brinkhoff T (2004) A newly discovered 
Roseobacter cluster in temperate and polar oceans. Nature 427:445-448

Sherr BF, del Giorgio PA, Sherr EB (1999) Estimating abundance and single-cell characteristics of respiring bacteria via the redox dye CTC. Aquat Microb Ecol 18:117-131

Sherr EB, Sherr BF (1988) Role of microbes in pelagic food webs. Limnol Oceanogr 33:1225-1227

Sherr EB, Sherr BF (2000) Marine microbes: an overview. In: Kirchman DL (ed) Microbial ecology of the ocean. WileyLiss, New York, p 13-46

Sherry ND, Imanian B, Sugimoto K, Boyd PW, Harrison PJ (2002) Seasonal and interannual trends in heterotrophic bacterial processes between 1995 and 1999 in the subarctic NE Pacific. Deep-Sea Res II 49:5775-5791

Shiba T, Simidu U, Taga N (1979) Distribution of aerobic bacteria which contain bacteriochlorophyll a. Appl Environ Microbiol 38:43-45

Sieracki ME, Haugen EM, Cucci TL (1995) Overestimation of heterotrophic bacteria in the Sargasso Sea: direct evidence by flow and imaging cytometry. Deep-Sea Res 42:1399-1409

Sieracki ME, Gilg IC, Thier EC, Poulton NJ, Goericke R (2006) Distribution of planktonic aerobic anoxygenic photoheterotrophic bacteria in the northwest Atlantic. Limnol Oceanogr 51:38-46

Simon M, Azam F (1989) Protein content and protein synthesis rates of planktonic marine bacteria. Mar Ecol Prog Ser 51:201-213

Smith EM (1998) Coherence of microbial respiration rate and cell-specific bacterial activity in a coastal planktonic community. Aquat Microb Ecol 16:27-35

Sogin ML, Morrison HG, Hubert JA, Welch DM and others (2006) Microbial diversity in the deep sea and the underexplored 'rare biosphere'. Proc Natl Acad Sci USA 103: $12115-12120$

Sommaruga R, Obernosterer I, Herndl GJ, Psenner R (1997) Inhibitory effect of solar radiation on thymidine and leucine incorporation by freshwater and marine bacterioplankton. Appl Environ Microbiol 63:4178-4184

Southward EC (1987) Contribution of symbiotic chemoautotrophs to the nutrition of benthic invertebrates. In: Sleigh MA (ed) Microbes in the sea. Halsted Press, Chichester, p 83-118

Steele JH (1974) The structure of marine ecosystems. Harvard University Press, Cambridge, MA

Stepanauskas R, Sieracki ME (2007) Matching phylogeny and metabolism in the uncultured marine bacteria, one cell at a time. Proc Natl Acad Sci USA 104:9052-9057

Stingl U, Tripp HJ, Giovannoni SJ (2007) Improvements of high-throughput culturing yielded novel SAR11 strains and other abundant marine bacteria from the Oregon coast and the Bermuda Atlantic Time Series study site. ISME J 1:361-371

Stoderegger KE, Herndl GJ (1998) Production and release of bacterial capsular material and its subsequent utilization by marine bacterioplankton. Limnol Oceanogr 43:877-884

> Stoderegger KE, Herndl GJ (2001) Visualization of the exopolysaccharide bacterial capsule and its distribution in oceanic environments. Aquat Microb Ecol 26:195-199

Suzuki MT (1999) Effect of protistan bacterivory on coastal bacterioplankton diversity. Aquat Microb Ecol 20:261-272

Suzuki MT, Preston CM, Chavez FP, DeLong EF (2001) Quantitative mapping of bacterioplankton populations in seawater: field tests across an upwelling plume in Monterey Bay. Aquat Microb Ecol 24:117-127

Swingley WD, Sadekar S, Mastrian SD, Matthies HJ and others (2007) The complete genome sequence of Roseobacter denitrificans reveals a mixotrophic rather than photosynthetic metabolism. J Bacteriol 189:683-690

Taylor GT, Iabichella M, Ho TY, Scranton MI, Thunell RC, Muller-Karger F, Varela R (2001) Chemoautotrophy in the redox transition zone of the Cariaco Basin: a significant mid-water source of organic carbon production. Limnol Oceanogr 46:148-163

Teira E, Pazó MJ, Serret P, Fernández E (2001) Dissolved organic carbon production by microbial populations in the Atlantic Ocean. Limnol Oceanogr 46:1370-1377

Teira E, Lebaron P, van Aken H, Herndl GJ (2006) Distribution and activity of Bacteria and Archaea in the deep water masses of the North Atlantic. Limnol Oceanogr 51:2131-2144

Thingstad TF, Hagström Å, Rassoulzadegan F (1997) Accumulation of degradable DOC in surface waters: Is it caused by a malfunctioning microbial loop? Limnol Oceanogr 42:398-404

Thingstad TF, Havskum H, Kaas H, Nielsen TG and others (1999) Bacteria-protist interactions and organic matter degradation under P-limited conditions: analysis of an enclosure experiment and a simple model. Limnol Oceanogr 44:62-79

Thompson JR, Pacocha S, Pharino C, Klepac-Ceraj V and others (2005) Genotypic diversity within a natural coatal bacterioplankton population. Science 307:1311-1313

Unrein F, Alonso-Sáez L, Massana R, Gasol JM (2007) Significant year-round impact of small mixotrophic flagellates on bacterioplankton in an oligotrophic coastal ocean. Limnol Oceanogr 52:456-469

Varela MM, van Aken HM, Sintes E, Herndl GJ (2008) Latitudinal trends of Crenarchaeota and Bacteria in the mesoand bathypelagic water masses of the Eastern North Atlantic. Environ Microbiol 10:110-124

Venter JC, Remington K, Heidelberg JF, Halpern AL and others (2004) Environmental genome shotgun sequencing of the Sargasso Sea. Science 304:66-74

Vézina AF, Platt T (1988) Food web dynamics in the ocean. I. Best-estimates of flow networks using inverse methods. Mar Ecol Prog Ser 42:269-287

> Vila-Costa M, Simó R, Harada H, Gasol JM, Slezak D, Kiene RP (2006) Dimethylsulfoniorpopionate uptake by marine phytoplankton. Science 314:652-654

Ward BB (2000) Nitrification and the marine nitrogen cycle. In: Kirchman DL (ed) Microbial ecology of the oceans. Wiley-Liss, New York, p 427-453

Williams PJLeB (1981) Incorporation of microheterotrophic processes into the classical paradigm of the planktonic food web. Kiel Meeresforsch 5:1-28

Woebken D, Fuchs BM, Kuypers MMM, Amann R (2007) Potential interactions of particle-associated anammox bacterial with bacterial and archaeal partners in the Namibian Upwelling System. Appl Environ Microbiol 73:4648-4657

Worden AZ, Nolan JK, Palenik B (2004) Assessing the dynamics and ecology of marine picophytoplankton: the importance of the eukaryotic component. Limnol Oceanogr 49:168-179

Wuchter C, Herfort L, Coolen MJL, Abbas B and others (2006) Archaeal nitrification in the ocean. Proc Natl Acad Sci USA 103:12317-12322

Yurkov VV, Beatty JT (1998) Aerobic anoxygenic phototrophic bacteria. Microbiol Mol Biol Rev 62:695-724

Zhang Y, Jiao N (2007) Dynamics of aerobic anoxygenic phototrophic bacteria in the East China Sea. FEMS Microbiol Ecol 61:459-469

Zlotnik I, Dubinsky Z (1989) The effect of light and tempera- 
ture on DOC excretion by phytoplankton. Limnol Oceanogr 34:831-839

Zubkov MV, Tarran GA (2005) Amino acid uptake of Prochlorococcus spp. in surface waters across the South Atlantic Subtropical Front. Aquat Microb Ecol 40: 241-249

Zubkov MV, Fuchs BM, Tarran GA, Burkill PH, Amann R (2003) High rate of uptake of organic nitrogen compounds by Prochlorococcus cyanobacteria as a key to their dominance in oligotrophic oceanic waters. Appl Environ Micro-

Submitted: March 13, 2008; Accepted: July 31, 2008 biol 69:1299-1304

Zubkov MV, Tarran GA, Fuchs BM (2004) Depth related amino acid uptake by Prochlorococcus cyanobacteria in the Southern Atlantic tropical gyre. FEMS Microbiol Ecol 50:153-161

- Zwirglmaier K, Jardillier L, Ostrowski M, Mazard S and others (2008) Global phylogeography of marine Synechococcus and Prochlorococcus reveals a distinct partitioning of lineages among oceanic biomes. Environ Microbiol 10:147-161

Proofs received from author(s): August 28, 2008 